\title{
ANALISIS PEMBERIAN KREDIT PADA USAHA MIKRO KECIL MENENGAH TANPA AGUNAN PADA PT. BANK DANAMON TBK
}

\author{
Darma Syahrullah Ekajaya \\ Universitas Indonesia YPTK Padang, Indonesia \\ E-mail: darmasyahrullahekajaya@gmail.com
}

\begin{abstract}
Abstrak
Dengan semakin meningkatnya pertumbuha(penyaluran) kredit biasanya disertai pula dengan meningkatnya kredit yang bermasalah seperti kredit kurang lancar, kredit diragukan, dan kredit macet. Penelitian ini bertujuan untuk mengetahui dan menggambarkan mengenai bagaimana penyelesaian kredit mikro tanpa agunan yang bermasalah yang pada prinsipnya pada pencairan kredit pihak bank harus berpegang pada prinsip kehati-hatian dalam memproses kredit itu sendiri, yang realisasi dilapangan pihak PT.Bank Danamon Tbk Cabang Simpan Pinjam Pekanbaru. Berdasarkan hasil penelitian, proses penyelesaian kredit yang dilakukan oleh bank terhadap kredit tanpa agunan mikro adalah berupa penagihan/penarikan kembali dan penghapus bukuan. Tindakan yang dilakukan oleh bank dalam hal ini yaitu penagihan secara itensif yang dilakukan oleh bagian Hard Collector, menyarankan kepada debitur untuk menjual asetnya sebagai sumber pelunasan utangnya.
\end{abstract}

Kata kunci: Kredit, Agunan, UMKM

\section{Pendahuluan}

Setiap orang yang menjalankan usahanya baik secara perorangan maupun dalam bentuk perusahaan pasti membutuhkan pendanaan untuk mengembangkan usahanya tersebut. Kebutuhan dana tersebut baik bersifat jangka pendek maupun jangka panjang. Untuk mendapatkan dana yang dibutuhkan tidaklah mudah apalagi dengan cara menggali dana sendiri. Perusahaan tidak mungkin dapat mencari dana tersebut dari dalam karena tidak mungkin dapat diperoleh dalam jangka waktu yang pendek. Kebanyakan orang maupun perusahaan dalam menghadapi kekurangan dana salah satu jalan keluar yang dapat dilakukan adalah berutang kepada pihak lain. Dengan kata lain meminjam dana dulu pada kreditur nanti setelah jatuh tempo akan dibayar kembali. Sepintas lalu cara ini tampak mudah dilakukan, namun tidak demikian yang dialami oleh debitur sebenarnya.Untuk dapat memperoleh pinjaman tidaklah mudah, karena kreditur juga tidak sembarangan dalam meminjamkan uangnya. Kreditur mempunyai berbagai penilaian terhadap debitur termasuk masalah kepercayaan pengembalian utang. Salah satu usaha bank yang telah cukup dikenal di masyarakat adalah memberikan dana pinjaman atau utang kepada nasabahnya. Kedudukan bank dan nasabahnya adalah sederajat didalam perjanjian utang piutang, namun dari segi ekonomi dan sosial kedudukan bank lebih tinggi daripada nasabah karena bank mempunyai fasilitas yang dimanfaatkan oleh nasabahnya.

Kebersamaan Usaha Mikro, Kecil, dan Menengah (UMKM) dan bank komersial merupakan salah satu dari sekian banyak bentuk simbiose mutualisme dalam ekonomi. Dan kebersamaan tersebut bukan saja bermanfaat bagi keduanya, tetapi juga bagi masyarakat dan 


\section{http://lppm.upiyptk.ac.id/ojs3/index.php/MAJALAHILMIAH/index}

pemerintah. Usaha mikro, kecil dan menengah juga membutuhkan modal demi kelangsungan usahanya, sama seperti usaha-usaha lain. Saat ini pemerintah sedikit banyak telah memberikan bantuan berupa program-program pemberian kredit lunak dalam rangka pemberdayaan usaha mikro kecil dan menengah, namun keterbatasan dana dari pemerintah mengakibatkan tidak seluruh usaha mikro, kecil dan menengah mendapat saluran dana dari program-program pemerintah tersebut. Sebagian besar dari pelaku usaha mikro, kecil dan menengah mengajukan kredit secara mandiri kepada Bank untuk mengatasi masalah keuangan dalam kelangsungan usahanya.

Agunan merupakan salah satu unsur pemberian kredit yang digunakan sebagai alternatif dalam pembayaran kredit apabila debitur tidak melakukan kewajibannya. Agunan kredit terdiri dari agunan pokok dan agunan tambahan. Agunan pokok dapat berupa barang, surat berharga, atau garansi, yang berkaitan langsung dengan objek yang dibiayai dengan kredit yang bersangkutan, seperti barang-barang yang dibeli dengan kredit yang bersangkutan, maupun tagihan-tagihan debitur kepada pihak lain. Sedangkan agunan tambahan dapat berupa barang, surat berharga, atau garansi, yang tidak berkaitan langsung dengan objek yang dibiayai dengan kredit yang bersangkutan, yang ditambahkan sebagai agunan. Agunan tambahan tidak bersifat pokok, artinya tanpa agunan itu pun bank tetap dapat memberikan kredit kepada nasabah debitur, asalkan syarat jaminan kredit dan agunan pokok telah dipenuhi.

Kota Pekanbaru merupakan salah satu kota di Indonesia yang sedang pesat pertumbuhan UMKM. Data Diskop dan UKM Riau menyebutkan, untuk Propinsi Riau sendiri, pertumbuhan UMKM Kota Pekanbaru berada pada posisi pertama dengan jumlah UMKM sebanyak 68.728. Data UKM tersebut sangat berguna untuk pengelompokkan UKM sesuai bidangnya dan guna mengetahui lebih detail pertumbuhan UKM di Pekanbaru. Disamping juga bisa dijadikan sebagai rekomendasi bagi BUMN untuk memberikan pinjaman lunak kepada para pengelola UKM. Angka di atas terus meningkat seiring dengan geliat perkembangan pembangunan Kota Pekanbaru yang semakin maju.

Salah satu bank swasta nasional di Kota pekanbaru yang memberikan kredit mikro (pelayanan fkeuangan yang diperuntukkan bagi pengusaha mikro berpenghasilan rendah) adalah PT. Bank Danamon, melalui salah satu divisinya yaitu Danamon Simpan Pinjam (DSP). Danamon Simpan Pinjam saat ini memiliki portfolio segmen mass market atau usaha mikro, kecil, dan menengah sebesar 52 persen dari portfolio kredit dan berencana untuk melakukan ekspansi kredit mikro tahun ini. Saat ini Danamon Simpan Pinjam sudah memiliki 300 ribu nasabah existing dan itu masih bisa dilakukan penambahan. Pemberian kredit mikro pada Danamon Simpan Pinjam ini menjadi solusi terbaik dan mudah bagi masyarakat UMKM di Kota Pekanbaru, karena dapat mengajukan dan mendapatkan pinjaman tanpa perlu agunan. Pada Danamon Simpan Pinjam produk pinjaman usaha mikro tanpa agunan ini dinamakan dengan program Solusi Modal. Solusi Modal adalah pinjaman jangka pendek tanpa agunan untuk modal usaha atau keperluan lainnya.

Dengan semakin meningkatnya pertumbuhan (penyaluran) kredit biasanya disertai pula dengan meningkatnya kredit yang bermasalah. Walaupun tidak semua nasabah kredit bermasalah, tetapi tetap saja timbul beberapa kasus kredit yang bermasalah. Kredit bermasalah ialah kredit yang tergolong kredit kurang lancar,kredit diragukan, dan kredit macet.

Berdasarkan hal-hal yang telah dikemukakan di atas, maka penulis tertarik untuk melakukan penelitian guna mengetahui dan menggambarkan mengenai bagaimana penyelesaian kredit mikro tanpa agunan yang bermasalah yang pada prinsipnya pada pencairan kredit pihak bank harus berpegang pada prinsip kehati-hatian dalam memproses kredit itu sendiri, yang realisasi dilapangan pihak PT.Bank Danamon Tbk cabang simpan pinjam pekanbaru kurang menerapkan prinsip kehati-hatian yang akibatnya menimbulkan kredit yang dikucurkan oleh PT.bank Danamon Tbk cabang pembantu simpan pinjam pekanbaru menimbulkan kredit macet. Oleh karena itu penulis akan mengangkat permasalahan yang ada pada PT. Bank Danamon Tbk Cabang pembantu simpan pinjam pekanbaru dengan judul "PENYELESAIAN KREDIT MIKRO TANPA AGUNAN PADA PT.BANK DANAMON TbK CABANG PEMBANTU 
http://lppm.upiyptk.ac.id/ojs3/index.php/MAJALAHILMIAH/index

Vol. 25 Issue 2 , Hal 263-276

ISSN : 1412-5854 |e-ISSN : 2502-877

\section{SIMPAN PINJAM PEKANBARU".}

\section{Tinjauan Literatur}

\subsection{Perjanjian}

Dalam Kitab Undang-Undang Hukum Perdata pasal 1313 dinyatakan bahwa : "perjanjian adalah suatu perbuatan dengan mana satu orang atau lebih mengikatkan dirinya terhadap satu orang atau lebih". Menurut R. Subekti, (Hukum Perjanjian, Intermassa, Jakarta, 2002, Hal 1), perjanjian adalah suatu hubungan hukum kekayaan atau harta benda antara dua orang atau lebih, yang memberi kekuatan hak pada satu pihak untuk memperoleh prestasi dan sekaligus mewajibkan pada pihak lain untuk menunaikan prestasi. Hubungan antara perikatan dengan perjanjian adalah setiap perjanjian menimbulkan suatu hubungan hukum antara pihak-pihak yang membuatnya, hubungan antara para pihak itu dinamakan perikatan, dengan demikian setiap perjanjian merupakan sumber perikatan.

\subsection{Perjanjian Kredit}

Bank berfungsi sebagai penghimpun dana dan menyalurkannya kepada masyarakat dalam rangka meningkatkan taraf hidup rakyat banyak. Penyaluran dana dari bank kepada masyarakat salah satunya adalah dalam bentuk kredit. Istilah kredit berasal dari bahasa Romawi, yaitu credere yang berarti percaya, atau credo artinya saya percaya. Menurut H.R. Daeng Naja (Hukum Kredit dan Bank Garansi, PT. Citra Aditya Bakti Bandung, 2005, Hal 125), pada prakteknya secara umum jenis-jenis kredit yang diberikan oleh Bank kepada nasabahnya, yaitu :

1. Jenis kredit yang ditinjau dari segi penggunaannya, dapat berupa :

a. Kredit produktif, yaitu kredit yang diberikan kepada usaha-usaha yang menghasilkan barang dan jasa sebagai kontribus dari usahanya. Terdiri dari:

1) Kredit modal kerja, yaitu kredit yang diberikan untuk membiayai kebutuhan usahausaha, guna menutupi biaya produksi dalam rangka peningkatan produksi atau penjualan.

2) Kredit investasi, yaitu kredit yang diberikan untuk pengadaan barang modal maupun jasa yang dimaksudkan untuk menghasilkan suatu brang dan maupun jasa bagi usaha yang bersangkutan.

b. Kredit Konsumtif, yaitu kredit yang diberikan kepada orang perorangan untuk memenuhi kebutuhan konsumtif masyarakat umumnya (sumber pengembaliannya dari fixed income debitur)

2. Jenis kredit berdasarkan jangka waktunya, yaitu :

a. Kredit Jangka Pendek, yaitu kredit yang jangka waktunya tidak melebihi 1 (satu) tahun

b. Kredit Jangka Menengah, yaitu kredit yang mempunyai jangka waktu antara 1 (satu) sampai 3 (tiga) tahun.

c. Kredit Jangka Panjang, yaitu kredit yang mempunyai jangka waktu di atas 3 (tiga) tahun.

\subsection{Jaminan dan Agunan Kredit}

\subsubsection{Jaminan Kredit}

Pasal 1131 KUHP Perdata menentukan pengertian jaminan adalah segala kebendaan siberutang, baik yang bergerak maupun yang tidak bergerak, baik yang sudah ada maupun yang baru akan ada dikemudian hari, menjadi tanggungan untuk segala perikatan perseorangan. Fungsi 


\section{MAJALAH ILMIAH}

\section{http://lppm.upiyptk.ac.id/ojs3/index.php/MAJALAHILMIAH/index}

Vol. 25 Issue 2 , Hal 263-276

ISSN : 1412-5854 |e-ISSN : 2502-877

Jaminan adalah sebagai sarana perlindungan bagi keamanan kreditur, yaitu memberi kepastian atas pelunasan utang debitur. Keberadaan jaminan merupakan persyaratan untuk memperkecil risiko Bank dalam menyalurkan kredit. Walaupun demikian, secara prinsip dan bukan persyaratan utama, Bank mempriotaskan dari kelayakan usaha yang dibiayainya sebagai jaminan utama bagi pengembangan kredit, sesuai dengan jadwal yan disepakati bersama. (Johannes Ibrahim, Mengupas Tuntas Kredit Komersial Dan Konsumtif Dalam Perjanjian Kredit Bank. Bandar Maju. Bandung. 2004. Hal. 71)

\subsubsection{Agunan Kredit}

Pasal 1 angka 23 Undang-Undang Nomor 10 tahun 1998 tentang Perubahan atas UndangUndang Nomor 7 Tahun 1992 tentang Perbankan memberi definisi tentang agunan yaitu : "jaminan tambahan yang diserahkan nasabah debitur kepada bank dalam rangka pemberian fasilitas kredit atau pembiayaan berdasarkan Prinsip Syariah". Kredit tanpa agunan atau yang dikenal dengan unsecured transaction adalah pinjaman tanpa terikat oleh sesuatu yang dijadikan agunan apapun. Namun begitu, kredit tersebut diputus semata-mata berdasarkan suatu keyakinan kreditur, atas kesanggupan debitur untuk melunasi kredit sesuai dengan yang diperjanjikan.

\subsection{Usaha Mikro, Kecil dan Menengah}

Menurut Pasal 1 Ayat (1) Undang-Undang Nomor 20 Tahun 2008 tentang Usaha Mikro, Kecil dan Menengah, usaha mikro adalah usaha produktif milik orang perorangan dan/atau badan usaha perorangan yang memenuhi kriteria usaha mikro sebagaimana diatur dalam Undang-Undang tersebut yaitu yang memenuhi kriteria seperti yang tercantum dalam Pasal 6 ayat (1). Kriteria tersebut adalah :

1. memiliki kekayaan bersih paling banyak Rp50.000.000,00 (lima puluh rupiah) tidak termasuk tanah dan bangunan tempat usaha; atau

2. memiliki hasil penjualan tahunan paling banyak Rp300.000.000,00 (tiga ratus juta rupiah).

Usaha menengah menurut Undang-Undang Nomor 20 Tahun 2008 tentang Usaha Mikro, Kecil dan Menengah adalah usaha ekonomi produktif yang berdiri sendiri, yang dilakukan oleh orang perseorangan atau badan usaha yang bukan merupakan anak perusahaan atau cabang perusahaan yang dimiliki, dikuasai, atau menjadi bagian baik langsung maupun tidak langsung dengan Usaha Kecil atau usaha besar dengan jumlah kekayaan bersih atau hasil penjualan tahunan sebagaimana diatur dalam Undang-Undang tersebut. Yaitu seperti yang tercantum dalam Pasal 6 Ayat (3) yaitu:

1. memiliki kekayaan bersih lebih dari Rp500.000.000,00 (lima ratus juta rupiah) sampai dengan paling banyak Rp10.000.000.000,00 (sepuluh milyar rupiah) tidak termasuk tanah dan bangunan tempat usaha; atau

2. memiliki hasil penjualan tahunan lebih dari Rp2.500.000.000,00 (dua milyar lima ratus juta rupiah) sampai dengan paling banyak Rp50.000.000.000,00 (lima puluh milyar rupiah).

\subsection{Tinjauan Kredit Bermasalah}

1. Kredit Bermasalah

Kredit bermasalah adalah suatu keadaan dimana nasabah sudah tidak sanggup membayar sebagian atau seluruh kewajibannya kepada bank seperti yang telah diperjanjikan atau telah ada suatu indikasi potensial bahwa sebagian atau keseluruhan kewajibannya kepada bank 


\section{http://lppm.upiyptk.ac.id/ojs3/index.php/MAJALAHILMIAH/index}

tidak akan mampu dilunasi debitur. Yang termasuk dalam kredit bermasalah adalah kredit dengan kualitas kurang lancar, diragukan dan macet. Kredit yang masuk dalam golongan lancar dinilai sebagai kredit yang performing loan, sedangkan kredit yang masuk golongan kurang lancar, diragukan dan macet dinilai sebagai kredit non performing loan (Sutarno, Op Cit. Hal. 263).

Sesuai dengan ketentuan yang tercantum dalam Pasal 12 ayat (1) Peraturan Bank Indonesia Nomor 7/2/PBI/2005 tentang Penilaian Kualitas Aktiva Bank Umum dinyatakan bahwa penetapan kualitas kredit dilakukan dengan melakukan analisis terhadap faktor penilaian sebagaimana ditentukan dalam Pasal 10, yaitu mengenai prospek usaha, kinerja debitur dan kemampuan membayar.

2. Penyebab Terjadinya Kredit Bermasalah

Kredit merupakan salah satu kegiatan utama bank. Penyaluran kredit kepada nasabah yang tidak sesuai dengan prinsip-prinsip pemberian kredit, sering kali menjadi penyebab kredit bermasalah. Bank sebagai kreditur harus berusaha semaksimal mungkin menerapkan ketentuan-ketentuan yang berlaku mengenai pemberian kredit kepada nsabahnya agar dapat memperkecil resiko kerugian yang diderita oleh bank. Beberapa pengalaman pahit perbankan membuat para petugas bank perlu meningkatkan kehati-hatian dalam mengantisipasi masalah yang dapat meningkatkan kredit bermasalah.

3. Penanganan Kredit Bermasalah

Keberadaan kredit bermasalah pada kredit yang telah dikucurkan oleh bank sudah tentu dapat menjadi beban bagi bank yang dapat mempengaruhi kinerja bank dalam melakukan usahanya, oleh karena terhadap kredit bermasalah harus segera dilakukan upaya-upaya baik itu tindakan penyelamatan kredit maupun tindakan penyelesaian kredit agar bank dapat terbebas dari adanya kredit bermasalah. Tindakan bank dalam usaha menyelamatkan dan menyelesaikan kredit bermasalah akan sangat bergantung pada kondisi kredit yang bermasalah itu sendiri. Untuk menyelamatkan dan menyelesaikan kredit bermasalah ada dua strategi yang ditempuh:

a. Penyelesaian kredit bermasalah melalui jalur non litigasi

Penyelesaian melalui jalur ini dilakukan melalui perundingan kembali antara kreditor dan debitor dengan memperingan syarat-syarat dalam perjanjian kredit. Jadi dalam tahap penyelamatan kredit ini belum memanfaatkan lembaga hukum karena debitor masih kooperatif dan usaha debitur masih mempunya prospek yang baik. Dalam tindakan penyelamatan kredit ini bank meminta komitmen kesanggupan debitur dalam melakukan pembayaran dan bank juga mempertimbangkan kelayakan dilakukannya restrukturisasi kredit. Restrukturisasi kredit merupakan bentuk penyelamatan kredit yang dilakukan oleh bank sebagai kreditur yang bertujuan untuk meringankan debitur dalam hal pengembalian utangnya.

b. Penyelesaian kredit bermasalah secara litigasi

1) Mengajukan gugatan ke pengadilan

a) Mengajukan gugatan ke Pengadilan Negeri dengan ketentuan Hukum Acara Perdata.

b) Eksekusi jaminan kredit

c) Parate Eksekusi Hak tanggungan.

d) Paksa Badan. Diatur oleh Peraturan mahkamah Agung Republik Indonesia nomor 1 tahun 2000 tanggal 30 Juni 2002 tentang lembaga paksa badan.

e) Pailit.

2) Penyelesaian kredit perbankan melalui BPBN

"Kredit bermasalah yang ada pada bank yang sedang dalam penyehatan berdasarkan Peraturan Pemerintah Nomor 27 Tahun 1999 diselesaikan oleh suatu lembaga yang disebut Badan Penyehatan Perbankan Nasional (BPPN)." Piutang yang diurusi oleh 


\section{MAJALAH ILMIAH}

\section{http://lppm.upiyptk.ac.id/ojs3/index.php/MAJALAHILMIAH/index}

Vol. 25 Issue 2 , Hal 263-276

ISSN : 1412-5854 |e-ISSN : 2502-877

BPPN dari Bank dalam Penyehatan meliputi:

1. Piutang yang sudah dialihkan kepada BPPN;

2. Piutang yang timbul sehubungan dengan Penanggungan hutang;

3. Penyerahan kekayaan oleh pihak lain kepada bank dalam penyehatan atau BPPN

\section{Hasil Penelitian dan Pembahasan}

\subsection{Faktor- Faktor Yang Menyebabkan Kredit Bermasalah dalam Perjanjian Kredit Tanpa Agunan Terhadap Usaha Mikro Pada PT.Bank Danamon Tbk Cabang Pembantu Simpan Pinjam Pekanbaru.}

Dalam penyaluran kredit tanpa agunan di PT.Bank Danamon Tbk cabang Pembantu Simpan Pinjam ternyata tidak selalu berakhir dengan pembayaran angsuran serta pelunasan oleh debitur secara lancar, seperti adanya keterlambatan pembayaran angsuran untuk pelunasan utang. Keterlambatan pembayaran angsuran ini menyebabkan debitur yang berdasarkan perjanjian yang telah disepakati sebelumnya, diwajibkan untuk membayar denda atas jumlah yang tidak dibayar. Akibatnya, jumlah angsuran yang wajib dibayarkan oleh debitur kepada pihak bank menjadi bertambah yaitu anguran pokok ditambah dengan denda atas keterlambatan pembayaran angsuran. Hal ini tentunya akan memberatkan debitur sebagai penalti akibat kelalaian debitur dalam memenuhi kewajibannya, sehingga pada akhirnya ada sebagian debitur yang tidak bisa melakukan pembayaran angsuran melebihi 91 (sembilan puluh satu) hari yaitu batas toleransi yang telah ditetapkan oleh bank mengenai keterlambatan pembayaran angsuran berdasarkan penjanjian yang telah disepakati sebelumnya oleh debitur dengan pihak bank.

PT.Bank Danamon Tbk cabang Pembantu Simpan Pinjam Pekanbaru menentukan penggolongan kualitas kredit tanpa agunan menjadi 3 (tiga) golongan, yaitu :

a. Lancar, yaitu apabila kondisi kredit tidak terdapat adanya tunggakan angsuran dalam artian pembayaran angsuran pokok dan bunga tepat waktu.

b. Special Mention, yaitu apabila terdapat tunggakan angsuran pokok dan atau bunga yang belum melampaui 90 (sembilan puluh) hari.

c. Non Performing Loan, yaitu apabila terdapat tunggakan angsuran pokok dan atau bunga yang melebihi 90 (sembilan puluh) hari.

Berdasarkan wawancara dengan kredit analis PT.Bank Danamon Tbk cabang pembantu simpan pinjam pekanbaru didapatkan informasi mengenai banyaknya pencairan kredit tanpa agunan di PT.bank danamon Tbk cabang pembantu simpan pinjam cabang pekanbaru dari bulan januari sampai bulan juni 2015 yang dituliskan pada tabel 1. Data jumlah nasabah macet mulai dari bulan januari sampai bulan juni 2015 yang dituliskan pada tabel 2 .

Tabel 1. Pencairan dari Bulan Januari sampai Juni 2015

\begin{tabular}{|c|c|c|c|}
\hline Bulan & Jumlah Nasabah & Pencairan & Total Pencairan \\
\hline Januari & 3 & 50.000 .000 & 150.000 .000 \\
\hline Februari & 4 & 50.000 .000 & 200.000 .000 \\
\hline Maret & 3 & 50.000 .000 & 150.000 .000 \\
\hline April & 3 & 50.000 .000 & 150.000 .000 \\
\hline Mei & 4 & 50.000 .000 & 200.000 .000 \\
\hline Juni & 3 & 50.000 .000 & 150.000 .000 \\
\hline Total & 20 & & 1.000 .000 .000 \\
\hline \multicolumn{3}{|l}{}
\end{tabular}




\section{MAJALAH ILMIAH}

http://lppm.upiyptk.ac.id/ojs3/index.php/MAJALAHILMIAH/index

Vol. 25 Issue 2 , Hal 263-276

ISSN : 1412-5854 |e-ISSN : 2502-877

Tabel 2. Jumlah Nasabah macet dari bulan Januari sampai Juni 2015

\begin{tabular}{|c|c|}
\hline Bulan & Jumlah Nasabah Macet \\
\hline Januari & 0 \\
\hline Februari & 0 \\
\hline Maret & 0 \\
\hline April & 0 \\
\hline Mei & 6 \\
\hline Juni & 2 \\
\hline Total & 8 \\
\hline
\end{tabular}

Berdasarkan wawancara penulis terhadap 8 (delapan) debitur yang melakukan pinjaman melalui Kredit Tanpa Agunan yang kreditnya pada saat itu termasuk dalam kualitas Non Performing Loan pada PT.Bank Danamon Tbk Cabang Pembantu Simpan Pinjam Pekanbaru ${ }^{1}$ yang penulis jadikan responden, responden mengungkapkan alasan-alasan yang berbeda kenapa mereka tidak memenuhi kewajibannya.

Tabel 3. Alasan debitur tidak memenuhi kewajibannya

\begin{tabular}{|c|c|c|}
\hline Penyebab Debitur Macet & $\begin{array}{l}\text { Jumalah debitur } \\
\text { (Orang) }\end{array}$ & Persentase \% \\
\hline $\begin{array}{l}\text { - } \text { Kondisi pasar yang sepi } \\
\text { - Kredit bukan untuk debitur tetapi } \\
\text { untuk orang lain } \\
\text { - Debitur melakukan perubahan } \\
\text { usaha } \\
\text { - Keuangan Debitur terfokus untuk } \\
\text { membantu saudara yang terkena } \\
\text { musibah. } \\
\text { - Salah satu aset usaha responden } \\
\text { dilarikan orang lain sehingga } \\
\text { usaha tidak berjalan dengan } \\
\text { optimal }\end{array}$ & $\begin{array}{l}3 \\
2 \\
1 \\
1\end{array}$ & $\begin{array}{c}37.5 \% \\
25 \% \\
12.5 \% \\
12.5 \% \\
12.5 \%\end{array}$ \\
\hline & 8 & $100 \%$ \\
\hline
\end{tabular}

Secara garis besar faktor-faktor yang dapat menjadi penyebab terjadinya kredit bermasalah dapat dibedakan dalam 2 (dua) golongan yaitu faktor internal dan faktor eksternal. Faktor internal dimaksud antara lain adalah:

a. Kurang tajamnya analis kredit.

b. Pengawasan dan administrasi kredit yang kurang baik.

c. Faktor pengikatan jaminan yang kurang sempurna.

d. Campur tangan pemilik bank yang berlebihan dalam pemberian kuasa.

Sedangkan faktor eksternalnya adalah:

a. Keadaan ekonomi yang tidak mendukung perkembangan usaha debitur.

b. Penggunaan kredit diluar dari yang direncanakan.

c. Itikad dan kemampuan debitur untuk melunasi dan dalam memenuhi persyaratan yang telah disepakati. 


\section{MAJALAH ILMIAH}

\section{http://lppm.upiyptk.ac.id/ojs3/index.php/MAJALAHILMIAH/index}

Vol. 25 Issue 2 , Hal 263-276

ISSN : 1412-5854 |e-ISSN : 2502-877

\subsection{Upaya Penyelesaian Kredit Bermasalah Dalam Perjanjian Kredit Tanpa Agunan Terhadap Usaha Mikro Pada PT.Bank Danamon Tbk cabang Pembantu Simpan Pinjam Pekanbaru.}

Dalam rangka penyaluran kredit kepada masyarakat, bank harus memperhatikan berbagai aspek analisis terhadap calon debitur. Langkah tersebut dilakukan sebelum perjanjian kredit ditandatangani untuk menjamin kepastian pelunasan oleh debitur nantinya. Setelah dilakukannya realisasi kredit, maka bank juga harus melakukan tindakan pengaman berupa supervisi/pengawasan/pengendalian kredit serta pembinaan debitur selama kredit tersebut disalurkan, agar tidak timbul kredit bermasalah dikemudian hari.

Supervisi/pengawasan/pengendalian kredit serta pembinaan debitur pada dasarnya adalah upaya pengamanan kredit yang dilakukan oleh bank dengan jalan terus memantau/memonitor dan mengikuti jalannya perusahaan (secara langsung/tidak langsung), serta memberikan saran/nasihat dan konsultasi agar perusahaan/debitur berjalan dengan baik sesuai dengan rencana, sehingga pengembalian kredit akan berjalan dengan baik pula. Tahapan supervisi ini pada umumnya dimulai pada saat pencairan kredit dan berakhir setelah semua kewajiban pada bank dilunasi oleh debitur.

Pada kredit tanpa agunan untuk usaha mikro pada PT.Bank Danamon Tbk cabang pembantu simpan pinjam pekanbaru, supervisi/pengawasan/pengendalian kredit serta pembinaan debitur dikenal dengan proses Maintenance. Proses maintenance ini dilakukan bagian Pick up Collector dengan cara menjaga hubungan baik serta pembinaan debitur pada saat penarikan angsuran baik secara harian (dayly pick up) maupun mingguan. Pada saat penarikan angsuran kredit tersebut, Pick up Collector senantiasa memantau perkembangan usaha debitur dan bahkan tidak jarang debitur meminta saran kepadanya demi perkembangan usaha debitur, sehingga terjadi komunikasi yang baik antara pihak bank dengan debiturnya.

Pada umumnya, sebelum mendapatkan apa yang dikehendakinya, calon debitur biasanya akan lebih patuh dan mudah untuk diajak kerjasama oleh bank. Namun apabila kreditnya telah disetujui, maka tidak jarang debitur susah untuk berkerjasama sama dalam mematuhi apa yang telah diperjanjikan olehnya, seperti halnya dalam hal keterlambatan membayar angsuran kredit sehingga menimbulkan kredit bermasalah. Keterlambatan pembayaran angsuran kredit yang penulis temukan terhadap debitur yang penulis jadikan responden berbeda-beda, antara lain :

Tabel 4. Keterlambatan pembayaran angsuran debitur pada kreditur

\begin{tabular}{|c|c|c|}
\hline $\begin{array}{c}\text { Lama Keterlambatan } \\
\text { (Hari ) }\end{array}$ & $\begin{array}{c}\text { Jumlah Debitur } \\
\text { (Orang ) }\end{array}$ & Persentase \% \\
\hline$-0-60$ hari & 0 & $0 \%$ \\
$-\quad 61-120$ hari & 6 & $75 \%$ \\
$-\quad 121-180$ hari & 2 & $25 \%$ \\
\hline & 8 orang & $\mathbf{1 0 0} \%$ \\
\hline
\end{tabular}

Bank akan melakukan berbagai macam upaya sesuai dengan kebijakan perkreditan yang ditetapkan didalam internal bank dan peraturan yang berlaku terhadap kredit bermasalah. Pada PT.Bank Danamon Tbk Cabang Pembantu Simpan Pinjam, upaya yang dilakukan agar kredit yang bermasalah kembali menjadi lancar dalam perjanjian kredit tanpa agunan mikro tersebut dilakukan sebelum kredit tersebut bermasalah. Upaya tersebut adalah dengan melakukan penagihan secara itensif serta melakukan pemantauan secara cermat mengenai perkembangan usaha debitur. Proses ini dilaksanakan oleh Pick up Collector sebagai tugasnya dalam hal cash pickup dan maintenance nasabah. Dari hasil pemantauan ini dapat diketahui mengenai sebab-sebab kenapa debitur bermasalah dalam kreditnya, sehinga bank dapat mentukan langkah-langkah selanjutnya dalam hal penyelamatan kredit. 


\section{http://lppm.upiyptk.ac.id/ojs3/index.php/MAJALAHILMIAH/index}

Vol. 25 Issue 2 , Hal 263-276

ISSN : 1412-5854 |e-ISSN : 2502-877

Dari hasil pemantauan ini Pick up Collector dapat menilai mengenai ada atau tidaknya itikad baik debitur dalam menyelesaikan kewajibannya kepada bank. PT.Bank Danamon Tbk Cabang Pembantu Simpan Pinjam menentukan klasifikasi debitur yang bermasalah, yaitu:

a. itikadnya baik, prospek usahanya ada.

b. itikadnya baik, prospek usahanya tidak ada.

c. itikadnya kurang, prospek usahanya ada.

d. itikadnya kurang, prospek usahanya tidak ada.

Itikad debitur untuk meyelesaikan kredit bermasalahnya dinilai berdasarkan penilaian mengenai kemauan dan kesediaan untuk :

a. Berinisiatif dan secara aktif melakukan negosiasi dengan kreditur.

b. Melakukan full disclosure mengenai keadaan usahanya kepada kreditur.

c. Memikul beban kerugian yang akan ditetapkan sebagai hasil negosiasi.

d. Mempunyai rencana restrukturisasi atau akan menyampaikan rencana restrukturisasi untuk dibahas dengan kreditur.

Prospek Usaha disimpulkan berdasarkan penilaian atas :

a. Potensi perusahaan untuk menghasilkan arus kas (net cash flow) yang positif.

b. Dampak multiplier yang dapat mempengaruhi perkembangan industri lainnya.

c. Tenaga kerja yang dipekerjakan.

d. Prospek pasar produk atau jasa yang dihasilkan.

e. Peluang peningkatan efisiensi dan daya saing.

Dari hasil klasifikasi penentuan debitur ini maka bank dapat menentukan langkah-langkah selanjutnya. Jika dalam pemantauan ternyata diketahui bahwa debitur tidak mempunyai itikad baik (seperti yang terdapat pada 2 (dua) orang responden yaitu 25\% dari total responden debitur yang beralasan bahwa mereka mengajukan kredit sebenarnya bukan diperuntukkan kepada mereka mereka namun untuk orang lain, mereka hanya sebagai perantara antara peminjam yang sebenarnya dengan pihak Bank. Hal ini membuktikan ketiadaan itikad baik debitur yakni kejujuran pada saat mengajukan suatu kredit), maka pihak bank akan melakukan penagihan-penagihan secara itensif dan kadang kala biasanya disertai dengan tekanan-tekanan dengan maksud untuk mempengaruhi psikologis debitur, sehingga diharapkan dapat memunculkan itikad baik debitur untuk segera menunaikan kewajibannya. Bila dari hasil pemantauan ternyata diketahui bahwa debitur mempunyai itikad baik, maka bank dapat mempertimbangkan untuk langkah penyelamatan kredit, dalam hal ini apakah relevan atau tidak bank melakukan restrukturisasi kredit. Pada PT.Bank Danamon Tbk cabang pembantu simpan pinjam pekanbaru, kondisi yang harus dipenuhi untuk dilakukannya restrukturisasi kredit adalah apabila :

a. Prospek usaha baik

b. Usaha debitur masih beroperasi dan akan berjalan terus

c. Kondisi keuangan debitur mempunyai potensi untuk kembali menjadi baik sehingga dapat kembali membayar kewajibannya dengan baik, dalam artian kondisi keuangan debitur yang saat itu menurun hanya bersifat sementara.

d. Debitur harus bersikap kooperatif, yaitu memiliki itikad baik dan bersedia mengungkapkan secara transparan seluruh data keuangan dan informasi penting lainnya, mempunyai sikap positf dalam pembayarannya.

Bentuk restrukturisasi yang dilakukan oleh PT.Bank Danamon Tbk Cabang Pembantu simpan Pinjam dalam hal perjanjian kredit tanpa agunan mikro adalah berupa perpanjangan jangka waktu kredit yang diikuti dengan perubahan besarnya angsuran kredit. Menurut pengakuan staff Collector PT.Bank Danamon Tbk Cabang Pembantu Simpan Pinjam restrukturisasi sangat jarang dilakukan pada kasus kredit bermasalah pada perjanjian kredit tanpa agunan mikro, sebab proses restrukturisasi yang rumit yang memerlukan persetujuan dari Area Manager melalui Unit 


\section{http://lppm.upiyptk.ac.id/ojs3/index.php/MAJALAHILMIAH/index}

Manager,sehingga restrukturisasi baru dipertimbangkan oleh bank untuk diberlakukan apabila ada permintaan oleh nasabah. Selain itu kecilnya nilai kredit yang dicairkan dan kecilnya angsuran untuk kredit tanpa agunan mikro dirasakan kurang efektif untuk dilakukannya restrusturisasi.

Upaya penyelesaian kredit bermasalah pada perjanjian kredit tanpa agunan mikro di PT.Bank Danamon Tbk Cabang Pembantu Simpan Pinjam sebenarnya telah dilakukan jauh sebelum kredit tersebut berstatus sebagai kredit dengan katagori Non Performing Loan. Upaya tersebut berbentuk penagihan secara itensif yang terpola kepada debitur dengan tingkatan yang berbeda, yaitu :

a. Keterlambatan 1 (satu) hingga 15 (lima belas) hari dilakukan oleh Collector.

b. Keterlambatan 16 (enam belas) hingga 30 (tiga puluh) hari dilakukan oleh Collector bersama dengan Sales Officer.

c. Keterlambatan 31 (tiga puluh hari) hingga 90 (sembilan puluh) hari dilakukan oleh Collector bersama Sales Officer, Kredit Analist dan Microbus Unit Head.

d. Keterlambatan lebih dari 91 (sembilan puluh) hari dilakukan oleh Hard Collector.

Penagihan secara itensif yang berbeda tersebut diatas, dilakukan setiap hari secara berkesinambungan. Dengan dilakukannya hal ini diharapkan menimbulkan tekanan pikologis yang berbeda bebannya sehingga debitur mempunyai beban moral bahkan dapat menimbulkan rasa malu dalam diri debitur, sehingga debitur dapat menyelesaikan utangnya atau paling tidak menunjukkan itikad baiknya dengan bersikap koorperatif terhadap bank.

Pada kasus keterlambatan pembayaran oleh debitur yang melebihi 91 (sembilan puluh satu) hari atau sudah termasuk kepada katagori Non Performing Loan pada perjanjian kredit tanpa agunan mikro, maka PT.Bank Danamon Cabang Pembantu Simpan Pinjam melakukan langkah penyelesaian kredit.

Langkah penyelesaian kredit yang dilakukan pada perjanjian kedit tanpa agunan mikro pada PT.Bank Danamon Tbk Cabang Pembantu Simpan Pinjam adalah penagihan atau penarikan kembali dengan cara pelunasan seluruh jumlah utang debitur secara sekaligus. Pada tahap ini, maka pihak bank melakukan upaya penagihan-penagihan terhadap debitur dengan harapan debitur membayar seluruh kewajibannya kepada bank. Berbeda dengan proses penagihan-penagihan sebelumnya, pada proses penagihan kali ini dilakukan oleh Hard Collector yang diharapkan dapat memberikan tekanan psikologis yang lebih berat bagi debitur dibandingkan dengan penagihanpenagihan sebelumnya. Penagihan ini sering dilakukan dengan disertai dengan tekanan-tekanan. Tidak jarang Hard Collector membawa polisi sebagai Shock Theraphy bagi debitur, bahkan biasanya Hard Collector berlama-lama di tempat kediaman debitur, dan baru akan pulang setelah debitur melunasi seluruh utangnya. Untuk itu, biasanya Hard Collector menyarankan kepada debtitur untuk mencari pinjaman kepada pihak lain untuk melunasi utangnya kepada debitur.

Jika dengan cara penagihan tersebut tidak berhasil, biasanya bank yang diwakili oleh Hard Collector menyarankan agar debitur bersedia untuk menjual asset pribadi debitur termasuk asset usaha debitur. Cara penagihan seperti ini ternyata efektif terhadap debitur yang tidak mempunyai itikad baik.

Langkah terakhir dalam penyelesaian kredit bermasalah pada perjanjian kredit tanpa agunan terhadap usaha mikro pada PT.Bank Danamon Tbk cabang Pembantu Simpan Pinjam adalah Write Off atau penghapus bukuan. Write Off dilakukan oleh PT.Bank Danamon Tbk cabang Pembantu Simpan Pinjam apabila berbagai upaya yang telah dilakukan dalam rangka penyelesaian kredit bermasalah tidak menuaikan hasil. Write off adalah penghapusan kewajiban debitur. Write offl penghapusbukuan tidak berarti kewajiban debitur kepada pihak bank telah dibebaskan, bank tetap mempunyai hak untuk menagih utangnya kepada debitur walaupun utangnya telah di hapusbukukan. Write off dilakukan oleh bank apabila memenuhi persyaratan:

a. Debitur memang tidak mempunyai kemampuan untuk membayar utangnya.

b. Debitur terlambar membayar lebih dari 1 (satu) tahun. 
http://lppm.upiyptk.ac.id/ojs3/index.php/MAJALAHILMIAH/index

Vol. 25 Issue 2 , Hal 263-276

ISSN : 1412-5854 |e-ISSN : 2502-877

c. Debitur kabur / melarikan diri.

\subsection{Pembahasan Penyelesaian Kredit Bermasalah Dalam Perjanjian Kredit Tanpa Agunan Terhadap Usaha Mikro Pada PT.Bank Danamon Tbk cabang Pembantu Simpan Pinjam Pekanbaru.}

Tindakan penyelesaian kredit dilakukan oleh PT.Bank Danamon Tbk Cabang Pembantu Simpan Pinjam terhadap kredit tanpa agunan mikro apabila bank menilai bahwa kredit yang bermasalah tersebut sudah tidak bisa untuk diselamatkan lagi. Berdasarkan hasil penelitian, proses penyelesaian kredit yang dilakukan oleh bank terhadap kredit tanpa agunan mikro adalah berupa penagihan/penarikan kembali dan penghapus bukuan.

Penagihan atau penarikan kembali kredit yang telah dicairkan oleh bank dilakukan apabila debitur telah terlambat melakukan pembayaran melebihi 91 (sembilan puluh satu) hari. Tindakan yang dilakukan oleh bank dalam hal ini adalah:

a. Penagihan secara itensif yang dilakukan oleh bagian Hard Collector. Pada penagihan ini debitur diminta untuk segera memenuhi kewajibanya kepada bank dengan membayar utangnya baik utang pokok, bunga serta denda. Utang yang ditagih bukan sejumlah angsuran dan denda namun utang debitur secara keseluruhan. Penagihan secara itensif ini dilakukan dengan pola yang terstruktur yaitu:

1) Mengirimkan surat pemberitahuan tertulis mengenai dikahirinya perjanjian dan memerintahkan kepada debitur untuk segera melakukan seluruh kewajibannya kepada bank dalam tempo waktu yang telah ditentukan oleh bank.

2) Melakukan penagihan dengan pendekatan persuasif dengan menyarankan debitur untuk segera melakukan pelunasan utangnya dalam waktu yang ditentukan oleh kedua belah pihak, dalam hal ini menyesuaikan dengan pertimbangan kemampuan dan kesanggupan bayar debitur. Melalui pendekatan persuasif diharapkan debitur dengan suka rela berinisiatif untuk melakukan pelunasan pembayaran utangnya.

3) Penagihan yang disertai dengan tekanan. Penagihan yang disertai dengan tekanan ini dilakukan oleh bank apabila pendekatan dengan pendekatan persuasif tidak berhasil. Proses penagihan yang disertai dengan tekanan-tekanan yang diharapkan dapat mempengaruhi psikologis debitur sehingga menimbulkan niat baik debitur dalam memenuhi kewajibannya. Tidak jarang Hard Collector membawa polisi sebagai Shock Theraphy bagi debitur, bahkan biasanya Hard Collector berlama-lama di tempat kediaman debitur, dan baru akan pulang setelah debitur melunasi seluruh utangnya. Untuk itu, biasanya Hard Collector menyarankan kepada debtitur untuk mencari pinjaman kepada pihak lain untuk melunasi utangnya kepada debitur.

b. Menyarankan kepada debitur untuk menjual asetnya sebagai sumber pelunasan utangnya. Aset debitur yang disarankan untuk dijual adalah aset pribadi debitur. Namun kadang kala bank menyarankan debitur untuk menjual aset usaha debitur apabila bank menilai aset pribadi debitur tidak cukup untuk melunasi utangnya.

Ketiadaan agunan merupakan kelemahan dalam perjanjian kredit tanpa agunan. Bank sebagai kreditur tidak boleh mengambil paksa aset debitur sebagai pelunasan utangnya tanpa didasari putusan pengadilan sebelumnya. Untuk itu sebelum adanya putusan pengadilan, bank hanya dapat menyarankan kepada debitur untuk menjual aset pribadi debitur.

Namun dengan disarankannya penjualan aset pribadi debitur menimbulkan dampak psikologis tersendiri kepada debitur. Cara seperti ini ternyata cukup ampuh dalam pengembalian utang debitur. Debitur biasanya setelah disarankan untuk menjual asetnya menjadi lebih giat dalam mencari solusi guna pelunasan utangnya. 


\section{http://lppm.upiyptk.ac.id/ojs3/index.php/MAJALAHILMIAH/index}

Pada standar perjanjian kredit tanpa agunan mikro pada PT.Bank Danamon Cabang Pembantu Simpan Pinjam dalam pasal 3 dicantumkan klausula bahwa dengan mengesampingkan jangka waktu kredit dalam pasal 1 , bank dapat menagih seluruh utang pokok berikut bunga serta biaya-biaya lain akibat perjanjian kepada debitur setelah pemberitahuan tertulis oleh bank mengenai diakhirinya perjanjian kredit tersebut bila mana :

a. Debitur dalam waktu 3 (tiga) bulan berturut-turut lalai melakukan pembayaran pokok dan/atau bunga atau lalai memenuhi kewajiban lainnya sebagaimana yang ditentukan dalam perjanjian

b. Data dan/atau surat-surat yang diberikan oleh Debitur kepada Bank ternyata tidak benar atau tidak sesuai dengan kenyataannya

c. Debitur tidak lagi berjualan ditempat sebagaimana yang telah diketahui oleh bank.

Dengan perumusan yang terdapat pada pasal 12 perjanjian kredit tanpa agunan tersebut telah jelas saat mana seorang debitur dikategorikan telah wanprestasi. Debitur yang penulis jadikan respoden semuanya telah nyata-nyata lalai melakukan pembayaran pokok dan/atau bunga melebihi 90 hari yaitu 3 bulan seperti yang tercantum dalam perjanjian mengenai batas waktu keterlambatan pembayaran yang mengakibatkan berakhirnya perjanjian kredit. Jika salah satu dari hal-hal tersebut yang tercantum dalam Pasal 3 standar perjanjian kredit tanpa agunan mikro pada PT.Bank Danamon Tbk cabang Pembantu Simpan Pinjam di atas dilanggar oleh debitur maka seluruh utang pokok berikut bunga serta biaya-biaya lain akibat dari perjanjian dapat ditagih seketika dan sekaligus oleh bank tanpa diperlukannya surat teguran dan harus diselesaikan selambat-lambatnya 10 (sepuluh) hari setelah pemberitahuan tertulis mengenai diakhirinya perjanjian tersebut.

Jika seorang debitur sudah diperingatkan sebelumnya dan secara tegas telah ditagih janjinya, tetapi ia tetap tidak melaksanakan prestasinya maka salah satu upaya hukum yang dapat ditempuh oleh kreditur untuk menuntut haknya adalah melakukan gugatan perdata melalui pengadilan. Proses gugatan di pengadilan yang rumit yang memakan waktu yang lama dan memakan biaya besar mengakibatkan bank enggan memakai bantuan pengadilan dalam hal kasus kredit bermasalah pada perjanjian kredit tanpa agunan mikro.

Pada prakteknya, apabila debitur telah nyata-nyata lalai menunaikan kewajibannya yaitu melakukan pembayaran pokok berikut bunga dan denda melebihi waktu 3 (tiga) bulan berturutturut, maka bank akan melakukan segala upaya guna meminta kesedian debitur untuk melunasi seluruh utang pokok berikut bunga serta segala kewajiban debitur. Upaya-upaya tersebut adalah berupa penagihan-penagihan yang bersifat itensif dan kadang kala disertai dengan tekanan-tekanan guna menjamin kesediaan debitur dalam menunaikan kewajibannya.

Pada dasarnya setiap penyelesaian kredit yang bermasalah, kreditur harus mengajukan gugatan perdata kepada debitur atau melakukan eksekusi atas jaminan-jaminan sesuai dengan peraturan perundang-undangan jika kreditur memiliki dasar hukum untuk melakukan eksekusi. Kreditur tidak diperkenankan memaksa, menakut-nakuti, mengancam, menciderai secara phisik atau melakukan kekerasan atau tindakan ntimidasi lainnya kepada debitur agar membayar utangnya. Tindakan-tindakan kreditur seperti itu meruakan tindakan yang ingin melaksanakan haknya sesuai kehendaknya sendiri dan sewenang-wenang yang dapat dikualifikasikan sebagai tindakan ain hakim sendiri .

Upaya-upaya yang dilakukan oleh PT.Bank Danamon Tbk Cabang Pembantu Simpan Pinjam dalam hal penyelesaian kredit bermasalah terhadap kredit tanpa agunan mikro dengan cara penagihan/penarikan kembari dinilai cukup sukses. Terbukti sejak PT.Bank Danamon Tbk Cabang Pembantu Simpan Pinjam mengeluarkan produk kredit tanpa agunan mikro hingga bulan agustus tahun 2010, pada kasus kredit bermasalah yang terjadi sebagian besar dapat diselesaikan dengan cara penagihan/penarikan kembali. Hanya terhadap 2 (dua) kasus kredit bermasalah yang diselesaikan dengan cara penghapusbukuan. 


\section{http://lppm.upiyptk.ac.id/ojs3/index.php/MAJALAHILMIAH/index}

Proses penyelesaian kredit bermasalah pada perjanjian kredit tanpa agunan terhadap usaha mikro yang dilakukan PT.Bank Danamon Tbk Cabang Pembantu Simpan Pinjam yang terakhir kali adalah Write Off / penghapusbukuan. Write Off atau penghapusbukuan dilakukan oleh bank apabila segala upaya yang telah dilakukan dalam kasus kredit bermasalah tidak membuahkan hasil. Write off adalah penghapusan kewajiban debitur dari pos yang ada di neraca Bank, antara lain pokok pinjaman, bunga (termasuk bunga pinjaman dan denda), biaya penagihan dan hukum. Tujuannya agar buku Bank sebagai kreditur tidak terbebani oleh Non Performing Loan (NPL). Write off/penghapusbukuan tidak berarti kewajiban debitur kepada pihak bank telah dibebaskan, bank tetap mempunyai hak untuk menagih utangnya kepada debitur walaupun utangnya telah di hapusbukukan. Write off dilakukan oleh bank terhadap debitur apabila memenuhi persyaratan sebagai berikut:

a. Debitur memang tidak mempunyai kemampuan untuk membayar utangnya.

b. Debitur terlambar membayar lebih dari 1 (satu) tahun.

c. Debitur kabur / melarikan diri.

Proses penghapusbukuan yang dilakukan oleh PT.Bank Danamon Tbk Cabang Pembantu Simpan Pinjam adalah dengan mengajukan pengusulan penghapusbukuan kepada direksi dengan mencantumkan alasan penghapusbukuan dengan mencantumkan identitas debitur, riwayat kredit dan penjelasannya. Penghapusbukuan kredit ini sifatnya rahasia intern bank, sehingga hanya diketahui oleh pihak bank saja. Penghapusbukuan tidak serta merta membebaskan debitur dari tanggung jawabnya, sehingga bank sewaktu-waktu dapat menagih kembali kepada debitur.

Sejak PT.Bank Danamon Tbk Cabang Pembantu Simpan Pinjam mengeluarkan produk kredit tanpa agunan mikro hingga bulan agustus tahun 2010, tercatat hanya pernah dilakukan penghapusbukuan terhadap 2 (dua) kasus kredit bermasalah. Hal ini dilakukan oleh bank dikarenakan debitur melarikan diri sehingga tempat kediaman debitur tidak diketahui.

\section{Kesimpulan}

Berdasarkan penelitian yang dilakukan, didapatkan kesimpulan sebagai berikut :

1. Penyebab kredit bermasalah dalam perjanjian kredit tanpa agunan usaha mikro pada PT Bank Danamon Tbk cabang pembantu simpan pinjam pekanbaru terdapat pada pihak debitur kreditur serta faktor luar . faktor kesalahan pada pihak debitur antara lain yaitu karakter yang kurang baik, kegagalan mengelola usaha, dan penyalahgunaan tujuan pemberian kredit .sedangkan pada pihak kreditur atau pihak bank yaitu ,kesalahan dalam terhadap menganalisa kredit ,kegagalan dalam melakukan pengawasan dan pembinaan kredit. Faktor diluar kesalahan debitur dan kreditur yang penulis temukan yaitu, kondisi perekonomian masyarakat yang menurun dan musibah yang dialami debitur .

2. Adapun upaya penyelesaian kredit bermasalah yang dilakukan oleh Bank Danamon Tbk cabang pembantu simpan pinjam Pekanbaru dalam perjanjian kredit tanpa agunan terhadap usaha mikro adalah tindakan penyelesaian kredit. Tindakan yang dilakukan antara lain yaitu , penagihan atau penarikan kembali kredit yang telah disalurkan. Dalam hal ini bank melakukan tindakan yang telah terpola yaitu, Penagihan secara itensif yang dilakukan oleh bagian Hard Collector. Penagihan secara itensif ini dilakukan dengan 3 tahap yaitu: Mengirimkan surat pemberitahuan tertulis mengenai diakhirinya perjanjian dan memerintahkan kepada debitur untuk segera melakukan seluruh kewajibannya kepada bank dalam tempo waktu yang telah ditentukan oleh bank, Melakukan penagihan dengan pendekatan persuasif dengan menyarankan debitur untuk segera melakukan pelunasan utangnya dalam waktu yang ditentukan oleh kedua belah pihak, dalam hal ini menyesuaikan dengan pertimbangan kemampuan dan kesanggupan bayar debitur,dan Penagihan yang disertai dengan tekanan. Tindakan berikutnya menyarankan kepada debitur untuk menjual asetnya sebagai sumber pelunasan utang atau Write Off/penghapus bukuan 


\section{MAJALAH ILMIAH}

\section{http://lppm.upiyptk.ac.id/ojs3/index.php/MAJALAHILMIAH/index}

Vol. 25 Issue 2 , Hal 263-276

ISSN : 1412-5854 |e-ISSN : 2502-877

\section{Referensi}

[1] Firdaus, H, Rahchmat dan Maya Ariyanti, 2003, Manajemen Perkreditan Bank Umum, Teori, Masalah, Kebijakan dan Aplikasinya Lengkap dengan Analisis Kredit, Alfabeta, Jakarta

[2] Fuady, Munir, 2002, Jaminan Fidusia, PT Citra Aditya Bakti, Bandung

[3] Gatot Supramono, 2009, Perbankan dan Masalah Kredit, PT Rineka Cipta, Jakarta

[4] Harahap, M. Yahya, 1986. Segi-Segi Hukum Perjanjian, Alumni, Bandung

[5] Hartono, Hadisoeprapto, 1984. Pokok-Pokok Hukum Perikatan Dan Hukum Jaminan, Liberty, Yogyakarta

[6] Hasan, Djuhaendah, 1996. Lembaga Jaminan Kebendaan Bagi Tanah Dan Benda Lain Yang Melekat Pada Tanah Dalam Konsepsi Penerapan Asas Pemisahan Horisontal (Suatu Konsep Dalam Menyongsong Lahirnya Lembaga Hak Tanggungan), PT.Citra Aditya Bakti, Bandung,

[7] Ibrahim, Johannes, 2004, Mengupas Tuntas Kredit Komersial Dan Konsumtif Dalam Perjanjian Kredit Bank, Bandar Maju, Bandung

[8] Iswi, hariyani,S.H, M.H, 2010, Restrukturisasi Dan Penghapusan Kredit Macet, PT.Elex Media Komputindo, Jakarta

[9] Kansil, 2000. Kamus Istilah Aneka Hukum, Pustaka Sinar Harapan, Jakarta

[10] Lincolin, Arsyad, 1999, Pengantar Perencanaan Pembangunan Dan

[11] Pembangunan Ekonomi Daerah, BPFE, Yogyakarta

[12] Mahmoeddin, As, 1991, Apakah Perjanjian Kredit Bank Itu, PT. Taka Gunung Agung, Jakarta:

[13] Muhammad, Abdul Kadir, 1992, Hukum Perjanjian, Alumni, Bandung

[14] Naja, H.R. Daeng, 2005, Hukum Kredit dan Bank Garansi, PT. Citra Aditya Bakti, Bandung

[15] Nawawi, Hadari, 2005, Metode Penelitian Bidang Sosial, Gadjah Mada University Press, Yogyakarta

[16] Salim, HS, 2004, Perkembangan Hukum Agunan Di Indonesia, Radja Grafindo Persada, Jakarta

[17] Setijoprojo, Bambang, 1993, Peraturan dan Kebijaksanaan Bank Indonesia dalam Mengurangi Kredit Macet, Bank Indonesia, Jakarta

[18] Simorangkir, O.P, 1986, Seluk Beluk Bank Komersial, Aksara Persada, Jakarta

[19] Soebekti, R, 2002, Hukum Perjanjian, Intermassa, Jakarta

[20] Sofwan, Sri Soedewi Masjcoen, Hukum Jaminan Di Indonesia Pokok-Pokok

[21] Hukum Jaminan Dan Jaminan Perorangan, Liberty, Yogyakarta

[22] Sunggono, Bambang, 2005, Metode Penelitian Hukum, RajaGrafindo Persada, Jakarta

[23] Supramono, Gatot, 1996, Perbankan dan Masalah Kredit, Djambatan, Jakarta

[24] Sutarno, 2005, Aspek-Aspek Hukum Perkreditan Pada Bank, Alfabeta, Bandung

[25] Usman, Marzuki, 1998, Meningkatkan Bargaining Position Usaha Kecil Melalui Pengembangan Kolektif, Prolog. Konferensi Nasional Usaha Kecil, Tanggal 7-8 Oktober 1998. Jakarta. 